\title{
Effect of Continuous Versus Intermittent Bolus Gavage Feeding on Gastrointestinal Tolerance, Physical and Physiological \\ Parameters in Premature Infants
}

\author{
Sozan Hassan Abd El-Hamid Hassan ${ }^{1}$; Faten Shafik Mahmoud ${ }^{2}$; and Khadiga Mohammed \\ Said $^{3}$
}

1 B.SC. Nursing/2008, Nursing Specialist in El-Menshawy Hospital-Tanta

2 Professor of Pediatric Nursing, Faculty of Nursing, Benha University

3 Assistant Professor of Pediatric Nursing, Faculty of Nursing, Benha University

\begin{abstract}
Background: Enteral feeding is a safe mean of providing the nutritional requirements of premature infants. Aim of study: was to assess the effect of continuous versus intermittent bolus feeding on physical, physiological parameters and gastrointestinal tolerance in premature infants. Design: A quasi -experimental design was used. Setting: the study was conducted in neonatal intensive care unit at Benha University Hospital, Benha Teaching Hospital and Benha Specialized Pediatric Hospital. Sample: A convenient sample of 100 premature infants was divided into two equal groups; 50 infants who received continuous gastric feeding as group A and 50 infants who received intermittent bolus feeding as group B. Tools of data collection: the first tool is a structured interviewing questionnaire sheet to assess personal characteristics of nurses and assess nurses' knowledge regarding enteral feeding. The second tool is nurses' observational checklist regarding enteral feeding. The third tool is neonatal feeding intolerance assessment sheet to assess personal characteristics of premature infants, feeding pattern of premature infants and feeding intolerance criteria. The fourth tool is Neonatal physical and physiological parameters assessment sheet to assess physical and physiological parameters. Results: show that there was a statistically significant differences between the studied groups of premature infants in abdominal distention, vomiting, length, pulse and $\mathrm{o}_{2}$ saturation and a highly statistically significant differences in weight and respiratory rate. Conclusion: the study concluded that continuous feeding was more effective than intermittent bolus feeding for feeding premature infant. Infants who received continuous gastric feeding had more stability in physical parameters, more increase in weight and length, more stability in physiological parameters and more gastrointestinal tolerance than those who receive intermittent bolus gavage feeding. Recommendation: the study recommended the importance of educational programs about enteral feeding and its technique to improve their knowledge and practice.
\end{abstract}

Keywords: enteral feeding, continuous feeding, intermittent bolus feeding, premature infants. 


\section{Sozan Hassan Abd El-Hamid, Faten Shafik and Khadiga Mohammed}

\section{Introduction}

Premature infants are infants who are born before 37 weeks of gestational age. these infants are at increased risk for physiological immaturity. Also, they have more medical complications; one of these complications is poor sucking and incoordination between sucking and swallowing. So, these infants need NICU admission, need special feeding as enteral nutrition and need special nursing care (Stavis, 2019, Atimier, et.al.,2020).

Enteral feeding is a safe means of providing the nutritional requirements of infants who are unable to feed orally. These infants are usually too weak to suck effectively, are unable to coordinate swallowing and lack a gag reflex. Enteral feeding may be provided by continuous drip regulated via infusion pump or by intermittent bolus feeding (Wilson, et al., 2017, Wilson, et al., 2019).

Continuous gastric feeding is delivered by either gravity drip or infusion pump with rate set per hour. It has been successful in managing premature infants with delayed gastric emptying time, intractable diarrhea, necrotizing enterocolitis and high risk for aspiration. In addition, intermittent bolus feeding is given periodically throughout the 24 hours per day by gravity or pushing syringe down with nutrients. It is delivered four to eight times per day; each feeding lasting about 15 to 30 minutes. It is more similar to a normal feeding pattern, more convenient. It promotes intestinal growth, gut hormone secretion and bile flow but premature infant may be aspirated easily during this feeding, also it may cause bloating and diarrhea (Blackburn, 2018).
Premature infant has small physical parameters than full term infant. These parameters include weight, length and head circumference. Also, premature infant has different physiological parameters than full term infant because of problems that face them as respiratory distress and hypothermia. These physiological parameters include temperature, heart rate, respiration and blood pressure (Healthwise Staff, 2019).

Nurse working at NICU requires knowledge and skills encompassing antenatal factors, stages of fetal development, neonatal resuscitation and transition to extra-uterine life. Moreover, developmentally appropriate care, complications of prematurity and illness, congenital abnormalities, neonatal surgery, breastfeeding and nutrition. Neonatal nursing care is individualized, developmentally supportive and family- centered care (Kabeel and Eisa., 2017).

\section{Significance of the study:}

Recently World Health Organization (WHO) estimates that every year, about 15 million babies are born premature (before 37 weeks of gestation) and this number is rising. Across 184 countries, the rate of premature birth ranges from $5 \%$ in several European countries to $18 \%$ in some African countries (WHO, 2020).

\section{Aim of the study}

This study aimed to assess the effect of continuous versus intermittent bolus feeding on physical, physiological parameters and gastrointestinal tolerance in premature infants. 


\section{Effect of Continuous Versus Intermittent Bolus Gavage Feeding on Gastrointestinal}

Tolerance, Physical and Physiological Parameters in Premature Infants

\section{Research hypotheses}

1. Premature infants who receive continuous gastric feeding had more stability in physiological parameters than those who receive intermittent bolus gavage feeding.

2. Premature infants who receive continuous gastric feeding had increase in height, weight and head circumference than those who receive intermittent bolus gavage feeding.

3. Premature infants who receive continuous gastric feeding had more gastrointestinal tolerance than those who receive intermittent bolus feeding.

\section{Subjects and Methods}

\section{I- Technical design}

Technical design includes research design, settings, subjects and tools of data collection.

\section{Research design:}

A quasi- experimental design was used to conduct the study.

\section{Settings:}

The study was conducted at Neonatal Intensive Care Unit at Benha University Hospital, Benha Teaching Hospital and Benha Specialized Pediatric Hospital.

\section{Subjects:}

A convenient sample of 100 premature infants was divided into two equal groups; 50 infants who received continuous gastric feeding as group $\mathrm{A}$ and 50 infants who received intermittent bolus feeding as group B. In each study setting, the subjects were assigned to group A or group B as follows: one subject for group A then the other for group B and so on.

\section{Inclusion criteria:}

1. Male and female infants less than 37 weeks of gestational age.

2. Infants receive feeding by gavage tube.

3. Infants have no congenital anomalies.

4. Infants have no gastrointestinal tract problems.

\section{Tools of data collection:}

Data is collected through the following tools:

Tool 1(Appendix II): A structured Interviewing Questionnaire Sheet: It was developed by the researcher after thorough review of the related literature, articles, magazines and websites (Mangili et al., 2017). It was written in Arabic language. It contained 2 parts:

Part 1) Personal Characteristics of nurses included: work place, age, gender, education and years of experience.

Part 2) Knowledge of nurses regarding intermittent and continuous bolus feeding as definition, technique, advantages, disadvantages. It composed of closed ended questions and contained 17 questions.

\section{Scoring system for nurses' knowledge:}

\begin{tabular}{|c|l|}
\hline Scoring item & score \\
\hline $\begin{array}{c}\text { Correctly and } \\
\text { completely answer }\end{array}$ & 2 \\
\hline $\begin{array}{c}\text { Correctly and } \\
\text { incompletely answer }\end{array}$ & 1 \\
\hline Incorrectly answer & 0 \\
\hline
\end{tabular}


Scoring system for level of total knowledge:

\begin{tabular}{|l|l|}
\hline $\begin{array}{l}\text { Level of } \\
\text { knowledge }\end{array}$ & percent \\
\hline Poor knowledge & From 0 to 10 \\
\hline $\begin{array}{l}\text { Moderate } \\
\text { knowledge }\end{array}$ & From 11 to 12 \\
\hline Good knowledge & From 23 to 34 \\
\hline
\end{tabular}

Tool 2(Appendix III): Nurses' observational checklist: it was adopted from Bowden, et al., (2016). It included hand washing, including 11 steps, nasogastric tube insertion including 11 steps, formula preparation including 11 steps and technique of intermittent and continuous bolus feeding including 17steps and 15 steps. It contained 65 steps as a total.

\section{Scoring system for nurses' practice:}

\begin{tabular}{|l|l|}
\hline Scoring item & score \\
\hline Correctly done & 1 \\
\hline Not done & 0 \\
\hline
\end{tabular}

According to the nurses' actual practice, their level of total practice was categorized as the following:

- Incompetent practice: $<80 \%$.

- Competent practice: $\geq 80 \%$.

Tool 3(Appendix IV): Neonatal Feeding Intolerance Assessment Sheet. It was developed by the researcher after thorough review of the related literature, articles, magazines and websites (Patel et al., 2018). It contained 3 parts:
Part 1) Personal characteristics of premature infants included: gender, age, date of admission, gestational age, Apgar score and medical diagnosis.

Part 2) Feeding pattern of premature infants included: feeding method, time when feeding start, type of milk, feeding amount, feeding frequency, time to reach full feeding, withheld feeding number.

Part 3) Feeding intolerance criteria included: gastric residual volume, abdominal distension, vomiting, unusual stool (color, frequency and consistency).

Scoring system for premature infants having problem before, during and after feeding:

\begin{tabular}{|l|l|}
\hline Scoring item & score \\
\hline Having problem & 1 \\
\hline $\begin{array}{l}\text { Not having } \\
\text { problem }\end{array}$ & 0 \\
\hline
\end{tabular}

Tool 4 (Appendix V): Neonatal physical and Physiological Parameters Assessment Sheet. It was developed by the researcher after thorough review of the related literature, articles, magazines and websites. It contained 2 parts:

Part 1) Physical Parameters Assessment Sheet included; birth and current weight in grams, birth and current length in centimeters, birth and current head circumference in centimeters.

Part 2) Physiological Parameters Assessment Sheet included; temperature, pulse, respiration, blood pressure and $\mathrm{O}_{2}$ saturation. 


\section{Effect of Continuous Versus Intermittent Bolus Gavage Feeding on Gastrointestinal}

Tolerance, Physical and Physiological Parameters in Premature Infants

\section{II- Operational design:}

This phase included preparatory phase, pilot phase and field work.

\section{Preparatory phase:}

A review of the past and current available literature was done using textbooks as (Wilson, et al.,2019), magazines, articles and websites to get acquainted with various aspects of the research problem, develop the tools for data collection.

\section{Tool validity:}

Tool validity was tested through a jury of 3 experts in pediatric nursing field to assess the tools for clarity, relevance, comprehensiveness, simplicity and applicability. The experts agreed on the content, but recommended with minor language changes that would make the information clearer and more precise. The suggested changes were made.

\section{Reliability of tools:}

Internal consistency reliability of all items of the tools was assessed using Cronbach's alpha coefficient.

\section{Ethical considerations:}

1- Each study subject was secured that the study does not carry any physical or psychological or social risks on neonates.

2- All the gathered data was treated confidentially and was used for research purpose only.

3- Each nurse had the right to withdraw at any time of the study without any rationale.

\section{Pilot study:}

Pilot study was carried out to $10 \%$ of the total sample (5 from each group) to test validity and reliability of the study tools during March 2018. Then the necessary modifications were done. The sample of pilot study did not include in the sample.

\section{Field work:}

The current study was carried out from the end of May 2018 to the beginning of February 2019. Official permission was obtained from the Dean of Benha Faculty of Nursing and the directors of the previous mentioned hospitals to collect the data after reviewing of past and current literatures. It started by interviewing the nurses at the previous mentioned settings. The researcher introduced herself to the nurses then explained the purpose of the study to them. The researcher was available at each study setting by rotation, two days per week during the morning shift.

The researcher gave the nurses checklist questions to fill it and assess their knowledge regarding enteral feeding. Each nurse was observed separately to assess her practice by using observational checklist during their actual practice. The nurses were not aware that the researcher was observing their practice during hand washing, insertion of enteral tube, formula preparation and technique of intermittent and continuous bolus feeding for premature infants.

The researcher selected the premature infant according to inclusion criteria. A simple random sample was done to classify the premature infants into group A (premature infants who received continuous gastric 


\section{Sozan Hassan Abd El-Hamid, Faten Shafik and Khadiga Mohammed}

feeding) and group B (premature infants who received intermittent bolus feeding) through serial numbers of cases. Each premature infant involved in the study was observed by the researcher and data were collected from medical records (this was taken nearly 15 minutes for each premature infant). Vital signs were measured and $\mathrm{o}_{2}$ saturation was observed using pulse oximeter before, during and after enteral feeding (intermittent and continuous). Also, the researcher observed any signs of feeding intolerance before, during and after feeding. Data collection was stopped from July 2018 to November 2018 on Benha University Hospital due to renovations and construction work.

\section{III-Administrative design:}

An official permission was obtained from the Dean of faculty of Nursing Benha University and administrators of the previously mentioned study settings.

\section{IV-Statistical design}

The collected data was organized, categorized and tabulated. Appropriate statistical methods were used for coding and analyzing results. Data were fed to the computer and analyzed using IBM SPSS software package version 20.0. (Armonk, NY: IBM Corp) Qualitative data were described using number and percent. Quantitative data were described using range (minimum and maximum), mean and standard deviation. Tests that were used (Chi-square test, Fisher's Exact or Monte Carlo correction, Student ttest, ANOVA with repeated measures). Test of Significance was used.

\section{Level of significant:}

$\mathrm{P}$ value> 0.05: No statistically significant difference.

$\mathrm{P}$ value< 0.05: statistically significant difference.

$P$ value $<0.001$ : Highly statistically significant difference

\section{Results}

Table1 indicated that more than half of the studied nurses $(57.8 \%)$ were in age group between $20-<30$ years. While $90.6 \%$ were females less than two fifths of them $(37.5 \%)$ had nursing bachelor. Regarding years of experience, less than two fifths of them (39.1\%) had experience in neonatal intensive care units from $5-<10$ years.

Table 2 illustrates that more than four fifths $81.3 \%$ of the studied nurses have correct and incomplete answers regarding definition of continuous enteral nutrition. While the vast majority $90.6 \%$ of them have correct and complete answer regarding types of enteral feeding

Figure 1: shows that more than two fifths $49 \%$ of the studied nurses answer questions related to enteral feeding completely and correctly but $6 \%$ of them answer incorrectly.

Figure (2): shows that more than four fifths $82.5 \%$ of the studied nurses do nasogastric tube and formula preparation correctly.

Table 3 shows that there was a statistically significant relation between personal data of the studied two groups of premature infants $(\mathrm{p}=<0.05)$ regarding their gender and gestational age. In addition, the vast majority $90 \%$ of group A and $80 \%$ of group B of the studied groups have RDS. 


\section{Effect of Continuous Versus Intermittent Bolus Gavage Feeding on Gastrointestinal}

Tolerance, Physical and Physiological Parameters in Premature Infants

Table 4 shows that there was a highly statistically significant relation $(\mathrm{p}<0.001)$ between the studied groups and their feeding methods, time when feeding start and feeding frequency /day. While there was a statistically significant relation between the studied groups and withheld feeding number $(\mathrm{p}<0.05)$.

Table (1): Distribution of the studied nurses according to their personal characteristics $(n=64)$

\begin{tabular}{|l|c|c||}
\hline \multicolumn{1}{|c|}{ Items } & No. & $\%$ \\
\hline Workplace & 10 & 15.6 \\
Benha University hospital & 12 & 18.8 \\
Benha teaching hospital & 42 & 65.6 \\
Specialized pediatric hospital & & \\
\hline Age & 3 & 4.7 \\
$<20$ years & 37 & 57.8 \\
$20-<30$ years & 22 & 34.4 \\
30 - <40 years & 2 & 3.1 \\
$\geq 40$ & $28.97 \pm 6.33$ \\
\hline Mean \pm SD & \multicolumn{2}{|c||}{} \\
\hline Gender & 6 & 9.4 \\
Male & 58 & 90.6 \\
Female & \multicolumn{2}{|c||}{} \\
\hline Education & 11 & 17.2 \\
Nursing diploma & 23 & 35.9 \\
Nursing institute & 24 & 37.5 \\
Nursing bachelor & 6 & 9.4 \\
Postgraduate nursing & 13 & 20.3 \\
\hline Years of experience & 16 & 25.0 \\
$<1$ year & 25 & 39.1 \\
1 - <5 years & 10 & 15.6 \\
\hline - <10 years & \multicolumn{2}{|c||}{} \\
$\leq 10$ years & \multicolumn{2}{|c||}{} \\
\hline
\end{tabular}


Table (2): Distribution of the studied nurses according to their knowledge $(n=64)$

\begin{tabular}{|l|c|c|c|c|c|c|}
\hline \hline \multirow{2}{*}{ Knowledge } & \multicolumn{2}{|c|}{ Incorrect } & \multicolumn{2}{c|}{$\begin{array}{c}\text { Incomplete } \\
\text { correct }\end{array}$} & \multicolumn{2}{c|}{$\begin{array}{c}\text { Complete } \\
\text { correct }\end{array}$} \\
\cline { 2 - 7 } & No. & $\%$ & No. & $\%$ & No. & $\%$ \\
\hline Definition of enteral nutrition. & 0 & 0.0 & 12 & 18.8 & 52 & 81.3 \\
Enteral feeding tube is inserted through. & 0 & 0.0 & 47 & 73.4 & 17 & 26.6 \\
cases that need enteral nutrition. & 0 & 0.0 & 17 & 26.6 & 47 & 73.4 \\
The benefits of enteral nutrition. & 0 & 0.0 & 18 & 28.1 & 46 & 71.9 \\
Types of enteral feeding. & 3 & 4.7 & 3 & 4.7 & 58 & 90.6 \\
Definition of intermittent enteral nutrition. & 21 & 32.8 & 43 & 67.2 & 0 & 0.0 \\
cases that need intermittent enteral nutrition. & 0 & 0.0 & 25 & 39.1 & 39 & 60.9 \\
Advantages of intermittent enteral feeding & 0 & 0.0 & 31 & 48.4 & 33 & 51.6 \\
Disadvantages of intermittent enteral feeding & 0 & 0.0 & 38 & 59.4 & 26 & 40.6 \\
Precautions when giving intermittent feeding. & 22 & 34.4 & 42 & 65.6 & 0 & 0.0 \\
Definition of continuous enteral nutrition. & 12 & 18.8 & 52 & 81.3 & 0 & 0.0 \\
cases that need continuous enteral nutrition. & 1 & 1.6 & 18 & 28.1 & 45 & 70.3 \\
Advantages of continuous enteral feeding & 2 & 3.1 & 42 & 65.6 & 20 & 31.3 \\
Disadvantages of continuous enteral feeding & 0 & 0.0 & 30 & 46.9 & 34 & 53.1 \\
Time to stop or reduce both type of feeding. & 0 & 0.0 & 19 & 29.7 & 45 & 70.3 \\
Precautions when giving continuous feeding. & 0 & 0.0 & 17 & 26.6 & 47 & 73.4 \\
The best type of feeding in nurses' opinion. & 0 & 0.0 & 52 & 81.3 & 12 & 18.8 \\
\hline
\end{tabular}

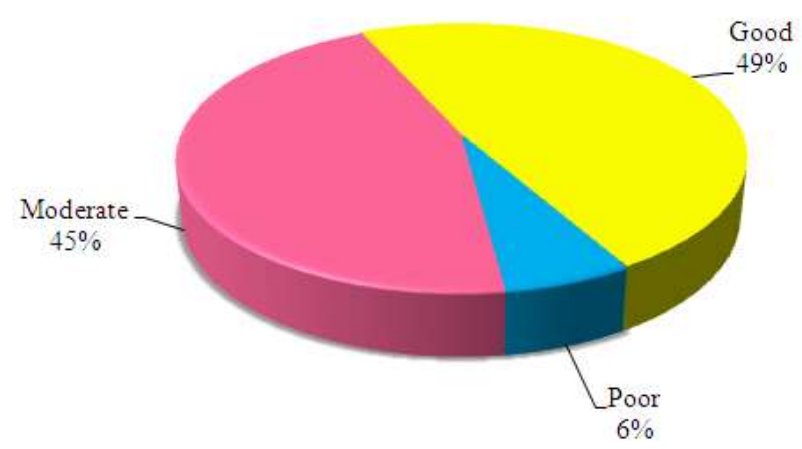

Figure (1): Distribution of the studied nurses according to their total knowledge regarding enteral feeding $(n=64)$ 


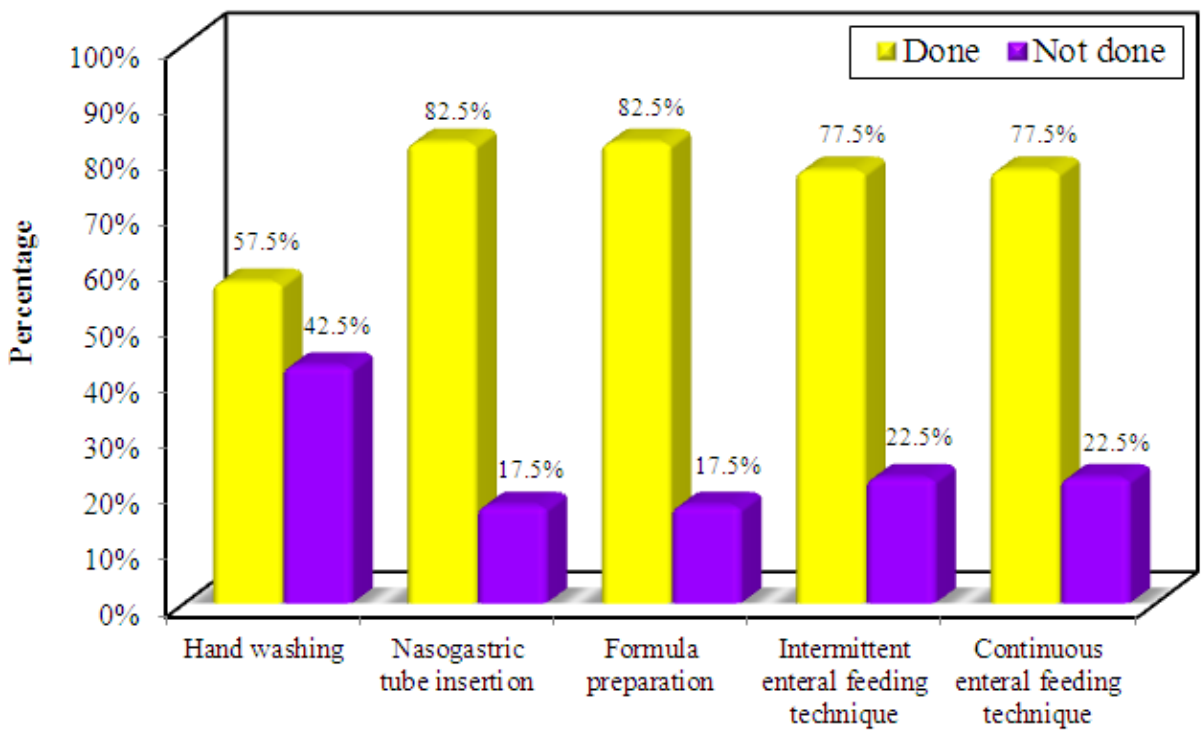

Figure (2):Distribution of the studied nurses according to their total practice during enteral feeding $(n=64)$

Table (3): Comparison between the two studied groups of premature infnts according to their personal characteristics

\begin{tabular}{|c|c|c|c|c|c|c|}
\hline & Contin & eeding & $\begin{array}{r}\mathrm{Gr} \\
\text { Intermit } \\
(\mathrm{n}\end{array}$ & eding & $\begin{array}{c}\text { Test of } \\
\text { Sig. }\end{array}$ & $\mathbf{p}$ \\
\hline & No. & $\%$ & No. & $\%$ & & \\
\hline $\begin{array}{l}\text { Gender } \\
\text { Male } \\
\text { Female }\end{array}$ & $\begin{array}{l}32 \\
18\end{array}$ & $\begin{array}{l}64.0 \\
36.0\end{array}$ & $\begin{array}{l}21 \\
29\end{array}$ & $\begin{array}{l}42.0 \\
58.0\end{array}$ & $\begin{array}{c}\chi^{2}= \\
4.857^{*}\end{array}$ & $0.028^{*}$ \\
\hline $\begin{array}{l}\text { Age } \\
1 \text { day } \\
2 \text { days to } 7 \text { days } \\
8 \text { days to } 14 \text { days } \\
15 \text { days and more } \\
\text { Mean } \pm \text { SD. }\end{array}$ & $\begin{array}{r}2 \\
18 \\
20 \\
10\end{array}$ & $\begin{array}{r}4.0 \\
36.0 \\
40.0 \\
20.0 \\
+4.44\end{array}$ & $\begin{array}{r}0 \\
16 \\
24 \\
10\end{array}$ & $\begin{array}{r}0.0 \\
32.0 \\
48.0 \\
20.0 \\
+9.37\end{array}$ & $\begin{array}{c}t= \\
0.791\end{array}$ & 0.431 \\
\hline 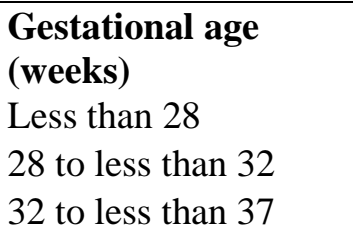 & $\begin{array}{l}16 \\
14 \\
20\end{array}$ & $\begin{array}{l}32.0 \\
28.0 \\
40.0\end{array}$ & $\begin{array}{r}3 \\
18 \\
29\end{array}$ & $\begin{array}{r}6.0 \\
36.0 \\
58.0\end{array}$ & $\begin{array}{c}\chi^{2}= \\
11.048 \\
*\end{array}$ & $0.004^{*}$ \\
\hline $\begin{array}{l}\text { Medical diagnosis } \\
\text { RDs } \\
\text { IUGR } \\
\text { Subdural hemorrhage }\end{array}$ & $\begin{array}{r}45 \\
5 \\
0\end{array}$ & $\begin{array}{r}90.0 \\
10.0 \\
0.0\end{array}$ & $\begin{array}{r}40 \\
9 \\
1\end{array}$ & $\begin{array}{r}80.0 \\
18.0 \\
2.0\end{array}$ & $\begin{array}{c}x^{2}= \\
2.340\end{array}$ & $\begin{array}{c}{ }^{M C} p= \\
0.267\end{array}$ \\
\hline
\end{tabular}

Group A:Infants received continuous gastric feeding Group B:infants received intermittent bolus feeding 
Table (4): Comparison between the two studied groups according to feeding pattern of premature infants

\begin{tabular}{|c|c|c|c|c|c|c|}
\hline \multirow[t]{2}{*}{ Items } & \multicolumn{2}{|c|}{$\begin{array}{l}\text { Group A } \\
\text { Continuous } \\
\text { feeding } \\
(\mathbf{n}=\mathbf{5 0})\end{array}$} & \multicolumn{2}{|c|}{$\begin{array}{c}\text { Group B } \\
\text { Intermittent } \\
\text { feeding } \\
(\mathbf{n}=\mathbf{5 0})\end{array}$} & \multirow[t]{2}{*}{$\chi^{2}$} & \multirow[t]{2}{*}{$\mathbf{P}$} \\
\hline & No. & $\%$ & No. & $\%$ & & \\
\hline $\begin{array}{l}\text { Feeding method } \\
\text { Intermittent bolus feeding } \\
\text { Continuous feeding }\end{array}$ & $\begin{array}{c}0 \\
50 \\
\end{array}$ & $\begin{array}{c}0.0 \\
100.0 \\
\end{array}$ & $\begin{array}{c}50 \\
0 \\
\end{array}$ & $\begin{array}{c}100.0 \\
0.0\end{array}$ & $100.0^{*}$ & $<0.001^{*}$ \\
\hline $\begin{array}{l}\text { Time when feeding start } \\
\text { Immediately at birth } \\
\text { On admission } \\
\text { After 2-7 days } \\
\text { Others }\end{array}$ & $\begin{array}{c}0 \\
3 \\
43 \\
4\end{array}$ & $\begin{array}{c}0.0 \\
6.0 \\
86.0 \\
8.0\end{array}$ & $\begin{array}{c}5 \\
13 \\
27 \\
5\end{array}$ & $\begin{array}{l}10.0 \\
26.0 \\
54.0 \\
10.0\end{array}$ & $14.965^{*}$ & $\begin{array}{c}{ }_{\mathrm{pC}}^{\mathrm{p}}= \\
0.001^{*}\end{array}$ \\
\hline $\begin{array}{l}\text { Type of milk for formula } \\
\text { feeding } \\
\text { Breast milk } \\
\text { Powdered milk } \\
\text { Both } \\
\end{array}$ & $\begin{array}{c}0 \\
13 \\
37 \\
\end{array}$ & $\begin{array}{c}0.0 \\
26.0 \\
74.0\end{array}$ & $\begin{array}{c}0 \\
12 \\
38 \\
\end{array}$ & $\begin{array}{c}0.0 \\
24.0 \\
76.0\end{array}$ & 0.053 & 0.817 \\
\hline $\begin{array}{l}\text { Feeding amount/ Feed } \\
\text { Less than } 30 \mathrm{ml} \\
30 \text { - Less than } 60 \mathrm{ml} \\
60 \text { - Less than } 90 \mathrm{ml} \\
90 \text { - Less than } 120 \mathrm{ml} \\
120 \mathrm{ml} \text { and more }\end{array}$ & $\begin{array}{c}18 \\
22 \\
10 \\
0 \\
0\end{array}$ & $\begin{array}{c}36.0 \\
44.0 \\
20.0 \\
0.0 \\
0.0 \\
\end{array}$ & $\begin{array}{c}24 \\
21 \\
5 \\
0 \\
0 \\
\end{array}$ & $\begin{array}{c}48.0 \\
42.0 \\
10.0 \\
0.0 \\
0.0 \\
\end{array}$ & 2.547 & 0.280 \\
\hline $\begin{array}{l}\text { Feeding frequency/day } \\
\text { Every } 2 \text { hours } \\
\text { Every } 3 \text { hours } \\
\text { As needed } \\
\text { Others }\end{array}$ & $\begin{array}{c}0 \\
0 \\
0 \\
50\end{array}$ & $\begin{array}{c}0.0 \\
0.0 \\
0.0 \\
100.0\end{array}$ & $\begin{array}{c}16 \\
34 \\
0 \\
0\end{array}$ & $\begin{array}{c}32.0 \\
68.0 \\
0.0 \\
0.0\end{array}$ & $100.0^{*}$ & $<0.001^{*}$ \\
\hline $\begin{array}{l}\text { Time to reach full feeding in } \\
\text { case of intermittent feeding } \\
\text { Less than } 5 \text { min } \\
5 \text { - Less than } 10 \text { min } \\
10 \text { - Less than } 15 \text { min } \\
15 \text { min and more }\end{array}$ & $\begin{array}{l}- \\
- \\
- \\
-\end{array}$ & $\begin{array}{l}\text { 0) } \\
- \\
- \\
- \\
-\end{array}$ & $\begin{array}{c}14 \\
16 \\
14 \\
6\end{array}$ & $\begin{array}{l}\text { 0) } \\
28.0 \\
32.0 \\
28.0 \\
12.0\end{array}$ & - & - \\
\hline $\begin{array}{l}\text { Withheld feeding number } \\
1-2 \\
3-4 \\
5 \text { and more } \\
\end{array}$ & $\begin{array}{c}44 \\
6 \\
0 \\
\end{array}$ & $\begin{array}{c}88.0 \\
12.0 \\
0.0 \\
\end{array}$ & $\begin{array}{c}31 \\
14 \\
5 \\
\end{array}$ & $\begin{array}{l}62.0 \\
28.0 \\
10.0 \\
\end{array}$ & $10.255^{*}$ & $\begin{array}{c}{ }_{\mathrm{pC}}^{\mathrm{p}}= \\
0.004^{*}\end{array}$ \\
\hline
\end{tabular}




\section{Effect of Continuous Versus Intermittent Bolus Gavage Feeding on Gastrointestinal}

Tolerance, Physical and Physiological Parameters in Premature Infants

\section{Discussion}

In this study, regarding distribution of the studied nurses according to personal characteristics, more than half of the studied nurses were in age group between 20 to less than 30 years. While more than four fifths of them were females that might due to the greater fraction of the nurses in Egypt was female. These findings agreed with a study by (Mohammed, 2019) about "Assessment of Nurses' Knowledge and Practices Regarding Nasogastric Tube at Neonatal Intensive Care Unit in Baghdad Hospitals" who found that, more than half of the studied nurses were in age group between 23 to 30 years and $68.6 \%$ of them were females.

The present study revealed that more than one third of the studied nurses had nursing bachelor. Also, nearly two fifths of them had experience in NICUs from 5 to less than 10 years. This result supported with a study by (Maheswari\&Muthamilseliv, 2014) about "Assess the effectiveness of structured teaching programme on universal precaution among class IV employees working at AarupadaiVeedu Medical College and Hospital" who found that $64 \%$ of the studied nurses had experience in NICU from 6 to 10 years. While these results disagreed with (Mohammed, 2019) who found $62.9 \%$ of the studied nurses had diploma and $45 \%$ of them had experience in NICU from 1 to 5 years.

Regarding nurses' knowledge about enteral feeding, the result revealed that more than two fifths of the studied nurses had complete and correct answer. This result agreed with a study by (Al-Kalaldeh, 2011) about "Enteral nutrition in the critically ill: A mixed methods study adherence to evidence- based protocols, nursing responsibility and team work" who found that $70 \%$ of the participants' scored less than $60 \%$ in knowledge comprehension regarding enteral nutrition.

Regarding nurses' practices during enteral feeding, the result revealed that more than four fifths of the studied nurses insert nasogastric tube and prepare formula correctly. This result agreed with a study by(Taha, 2004)about " Impact of a training program provided for nurses working in critical care units" who found that the subjects of his study showed the best performance related to nasogastric tube. While this result disagreed with a study by (Metwaly et al., 2013) about " Nurses' Performance Regarding Nasogastric Tube Feeding in Intensive Care Units" who found that the majority of nurses had unsatisfactory level of practice during nasogastric tube insertion.

The present study revealed that more than three fifths of the studied nurses wash hands before tube insertion. This result disagreed with (Metwaly et al., 2013) who found that the majority of the studied nurses did not perform hand washing before nasogastric tube insertion.

In this study, we concluded that, Practitioner nurses' level of knowledge and skills regarding nasogastric tube feeding in neonatal intensive care units were inadequate with some serious skills. That due to deficiency of policies, educational instruments and protocols regarding nasogastric tube feeding. The educational program had good effectiveness in promoting where marked nurses' more knowledgeable and promoting 


\section{Sozan Hassan Abd El-Hamid, Faten Shafik and Khadiga Mohammed}

skills regarding nasogastric tube feeding at the previous mentioned settings. We explain that these differences may be attributed to in adequate educational programs in that institutes. Each health care facility should improve nurses' knowledge through continues educational programs.

Some knowledge shortage was recorded regarding aspirate residual fluids in gastrointestinal tract with syringe, flush the tube with a small amount of sterile water after ending feeding and put child on his right side with elevated head of the bed and flush the tube with sterile water according to hospital policy or doctor order. These parameters need further educational programs.

In this study, regarding comparison between the two studied groups of premature infants according to personal characteristics, regarding gender, in group A less than two thirds of infants were males while in group B less than three fifths were females. Most common cause of admission in both groups was RDS. This finding of the present study agreed with a study of (Hakim, 2015) about "Assessing Nurses' Performance in Endotracheal Tube Suctioning in Neonatal Intensive Care Units" who found that $88 \%$ of the studied infants had RDS. Also, this finding of the present study agreed with a study of (Monsef et al., 2019) about "Evaluating the Short-Term Outcome of Mechanically Ventilated Neonates Admitted to the Neonatal Intensive Care Unit of Besat Hospital" who found that RDS was the most common cause of NICU admission.

Regarding gestational age, two fifths of infants in group A were between 32 to less than 37 weeks, while it was less than three fifths in group B, there was a statistically significant difference between both groups regarding gestational age $(\mathbf{P}=\mathbf{0 . 0 0 4})$. These findings of the present study agreed with a study of (Mahmoud et al., 2016) about "Effect of Endotracheal Suction Intervention on Oxygen Saturation Level in Preterm Infants" who found that $67 \%$ of the studied infants were between 32 to 36 weeks of gestational age.

Regarding feeding pattern, feeding started immediately at birth in only $10.0 \%$ in group $\mathrm{B}$, feeding started on admission in $6.0 \%$ in group A and in $26.0 \%$ in Group B, in the present study more than half of the studied infants in group B and more than four fifths in group A started feeding after 2-7 days. This finding of the present study agreed with a study of (Farhat et al., 2011) about "Comparison of Continuous and Intermittent Feeding Methods in Low Birth Weight Infants" who found that most infants started feeding 3-20 days.

The overarching goal while feeding VLBW infants is to reach full enteral feeding in the shortest time, while maintaining optimal growth and nutrition and avoiding the adverse consequences of rapid advancement of feeding. Attaining this goal is more difficult than it sounds, and controversies abound, Reaching full enteral feeding faster results in earlier removal of vascular catheters, and less sepsis and other catheter-related complications (Dutta et al., 2015).

\section{Conclusion}

Continuous feeding was more effective for feeding premature infant. Infants who received continuous gastric feeding had more stability in physical parameters, more increase 


\section{Effect of Continuous Versus Intermittent Bolus Gavage Feeding on Gastrointestinal}

Tolerance, Physical and Physiological Parameters in Premature Infants

in weight and length, more stability in physiological parameters (pulse, respiratory rate and $\mathrm{o} 2$ saturation), and more gastrointestinal tolerance than those who receive intermittent bolus gavage feeding

\section{Recommendations}

- Service education programs about enteral feeding and its technique should be designed and implemented to motivate nurses in achieving high competent care.

- Continuous monitoring of any signs of gastrointestinal intolerance and physiological parameters before, during and after enteral feeding

\section{References}

Al-Kalaldeh M., (2011): Enteral nutrition in the critically ill: A mixed methods study adherence to evidence- based protocols, nursing responsibility and team work, Access to Electronic Thesis of Sheffield University, $1-287$.

Atimier L., Kenner C.andBaykova M., (2020): Comprehensive Neonatal Nursing Care, $6^{\text {th }}$ ed., Springer, USA, ch:29, p.655 , 659.

Blackburn S.T., (2018): Maternal, Fetal \& Neonatal Physiology (A clinical perspective), Elsevier, USA, unit II, 5th ed., p. 426.

Bowden V. \& Greenberg C. (2016):

Dutta S., Singh B., Chessell L., Wilson J., Janes M., McDonald K., Shahid S., Gardner V.A., Hjartarson A., Purcha M., Watson J., (2015): Guidelines for feeding very low birth weight infants, Nutrients;7(1):423-42.
Farhat A.S., Khakshour A.\& Hosseini Z., (2011): Comparison of Continuous and Intermittent Feeding Methods in Low Birth Weight Infants, Iranian Journal of Neonatology IJN;2(1):8-11.

Hakim A., (2015): Assessing Nurses' Performance in Endotracheal Tube Suctioning in Neonatal Intensive Care Units, Iran Journal crit care Nurse,8(2): p. 89-94.

Health Wise Staff, (2019): Physical Growth in Newborns, Available at: https://myhealth.alberta.ca/Health/Pages/condi tions.aspx?hwid=te629

Health Wise Staff, (2019): Vital Signs in Children, Available at:

https://www. mottchildren.org/healthlibrary/abo2987

Kabeel A.R. \&Eisa S.A.: The Correlation of Critical Thinking Disposition and Approaches to Learning among Baccalaureate Nursing Students. J Educ Practice, [Internet]. 2016 [cited 2017 Mar 20]; 7 (32): 91-103.

Maheswari S. \&Muthamilselvi G., (2014): Assess the effectiveness of structured teaching programme on universal precaution among class IV employees working at AarupadaiVeedu Medical College and Hospital, Puducherry, India, American Journal of Nursing Research; 2: 26-30.

Mahmoud F.S., Khalaf S.M. \& Mohammed E.G., (2016): Effect of Endotracheal Suction Intervention on Oxygen Saturation Level in Preterm Infants, Master thesis, Faculty of Nursing, Benha University, p. 1-3. 


\section{Sozan Hassan Abd El-Hamid, Faten Shafik and Khadiga Mohammed}

Mangili G, Garzoli E., (2017): Feeding of preterm infants and fortification of breast milk. Pediatr Med Chir; 39:158.Medical and Health Research, Vol 4, Issue 6, p. 103-107.

Metwaly E.M., Mohammed E.H. \& Mohammed M., (2013): Nurses' performance Regarding Nasogastric Tube Feeding in Intensive Care Units, Zagazig Nursing Journal, Vol 9, No.1.

Mohammed A.Q., (2019): Assessment of Nurses' Knowledge and Practices Regarding Nasogastric Tube at Neonatal Intensive Care Unit in Baghdad Hospitals, Indian Journal of Public Health Research \& Development, Vol 10, No.4.

Monsef A.R., Eghbalian F., Sabzehei M.K., Khanlarzade E., (2019): Evaluating the Short-Term Outcome of Mechanically Ventilated Neonates Admitted to the Neonatal Intensive Care Unit of Besat Hospital, Hamadan, Iran. International Journal of Pediatrics.;7(9):10029-34.

Patel J.J., Rosenthal M.D.\& Heyland D.K., (2018): Intermittent versus continuous feeding in critically ill adults, Curr Opin Clin Nutr Metab Care; 21:116-20 Pediatric Nursing Procedures, $4^{\text {th }}$ ed.,

Royal National Institute of Blind People, (2018): Retinopathy of Prematurity, England, Available at http://www.rnib.org.uk/eyehealth-eye-conditions-z-eye-onditions

/retinopathy-prematurity

Singer P., (2011): ESPEN Guidelines on parental nutrition: neonatal intensive care. Clinical Nutrition; 28: 387-400.

Stanford Children's Health, (2019): Prematurity, Available at http://www.stanfordchildrens.org/en/topic/defa ult?id=prematurity-90p02401

Stavis R.L., (2019): Premature Newborn, Available at: http://www. Msdmanuals .com/home/children-s-health-issues/generalproblems-in-newborns/premature-newborn

Taha N.M., (2004): Comatosed patients: Impact of a training program provided for nurses working in critical care units, Zagazig University Hospital on nurses' knowledge and performance levels as well as on patient outcome, Faculty of Nursing, Zagazig University.

Wang Y., Zhu W., Luo B.R., (2019): Continuous feeding versus intermittent bolus feeding for premature infants with low birth weight: a meta-analysis of randomized controlled trials, European Journal of Clinical Nutrition; 28:1-9.

Wilson D., Hockenberry M. and Rodgers C., (2017): Wong's Essentials of Pediatric Nursing , $10^{\text {th }}$ ed., Elsevier, Canada, Unit 3, P. 242.

Wilson D., Hockenberry M. and Rodgers C., (2019): Wong's Nursing Care of Infants and Children, $11^{\text {th }}$ ed., Elsevier, Canada, Ch:9, p.279.

Wolters Kluter, China, PP. 275, 288-293.

World Health Organization (2020): Preterm birth. Available at:https://

www.who.int/news-room/fact-

sheets/detail/preterm-birth

Zhu L., (2013): Therapeutic concerns for oral medications are administrating nasogastrically. Journal of Clinical Pharmacy and Therapeutics; 11: 11-15. 
تأثير التغذية المعوية المستمرة مقابل التغذية المتقطعة على قدرة تحمل الجهاز الهضمي والتغيرات الفسيولوجية والجسمانية للأطفال المبتسرين

سوزان حسن عبدالحميد , فاتن شفيق محمود, خديجه محمد سعيد

تعد التغذية المعوية وسيلة آمنة لتلبية الاحتياجات الغذائية للرضع غير القادرين على التغذية عن طريق الفم. لذلك هدفت هذه الدراسة إلى تقييم تأثثر التغذية المعوية المستمرة مقابل التغذية المتقطعة على قدرة تحمل الجهاز الهضمي والتغير ات الفسيولوجية والجسمانية للأطفال المبتسرين. وقد أجريت الدر اسة في وحدات العناية المركزة لحديثي الو لادة بمستشفيات بنها الجامعي والتعليمي ومستشفى الأطفال التخصصي. وشملت العينة 100 طفل مبتسر. وقد أسفرت النتائج على وجود فروق ذات دلالة إحصائية بين المجموعات المدروسة من الاطفال المبتسرين في كل من انتفاخ البطن والقيء في نهاية الأسبوع بعد اول تغذية وقد خلصت هذه الدراسة أن التغذية المستمرة أكثر فعالية لتغذية الاطفال المبتسرين حيث كان لاى الرضع الذين تلقو التغذية المعوية المستمرة ثباتًا أكبر في المعايير الجسمانية، وزيادة في الوزن والطول، ومزيد من الثبات في المعايير الفسيولوجية (النبض، ومعدل التنفس، وتشبع الدم بنسبة الاكسجين)، وقدرة أكبر للمعدة لتحمل الغذاء أكثر من أولئك الذين يتلقون التغذية المعوية المتقطعة, أوصت الدر اسة بضرورة إعداد بر امج تعليمية وتدريبية دورية للممرضات العاملات بوحدات العناية المركزة اللاتي يقدمن رعاية تمريضية للأطفال المبتسرين عن التغذية المعوية. 